\title{
THE IMPACT OF MANAGING REARING CALVES ON THEIR PERFORMANCE IN A COMMERCIAL HOLSTEIN FRIESIAN FARM
}

\author{
S. Elkaschab, S. Omar, Elham M. Ghoneim and Asmaa S. Ghanem \\ Department of Animal Production, Faculty of Agriculture, Menofia University.
}

Received: Oct. 6,2020

Accepted: Oct. 18,2020

\begin{abstract}
This study was conducted in a commercial cattle farm named El-Baiomy dairy farm located in Gamasa- Dakahlia province-Egypt to evaluate the effect of management system on calves performance. Records of 3691 Holstein Friesian calves were used in this study from 2013 up to 2019. This study included management factors such as dam effect (dry period, parity, calving interval and previous milk production) and calves management (housing system, suckling system, season and gender) and their effects on birth weight $(\mathrm{kg})$, weaning weight $(\mathrm{kg})$, weaning age (day) and daily gain $(\mathrm{kg})$.

There was significant effect $(P \leq 0.05)$ of housing system, suckling system and season of calving on weaning age and daily gain of calves. The lowest birth weight was reported in winter $(31.34 \mathrm{~kg})$ however, the heaviest one was reported in winter $(93.88 \mathrm{~kg})$. The heaviest birth weight was reported in male $(32.93 \mathrm{~kg})$ but female was $31.63 \mathrm{~kg}$ only. On the other hand weaning age found to be 81.31 and 79.14 days in female and male, respectively. There were no significant effects $(P>0.05)$ in dry period length, parity, calving interval and previous milk production of dam on calf's performance. The lowest birth weight was found to be in first parity cows $(31.63 \mathrm{~kg})$, while the heaviest one was found to be in third parity cows $(33.00 \mathrm{~kg})$.
\end{abstract}

Key words: Rearing calves, housing system, season, gender.

\section{INTRODUCTION}

Calves are the future income of the farm and sustainability of farm depend on them. Calf management are important as they help calves in reaching their full genetic potential and can produce healthy herd replacement animals (Thakur and Gupta, 2016). Animals should be kept in a management system, which allow them to express natural behaviour.

Some farms fulfill low mortality rates, it indicates that losses can be avoided when good management practices are in place.

The early phase of the young animal's life is so crucial because the calves are very susceptible to the environmental and housing factors such as floor and bedding materials (Kartal and Yanar, 2011). Birth weight is an early and easy indicator of prenatal growth. The birth weight is commonly used as an early selection criterion in cattle breeding (Kaygısız et al., 2012). Concrete floors were preferable to individual dairy calves' pens, weights at weaning and 4 months of age were not significantly influenced by the type of floor (Kartal and Yanar, 2011).

Growth rate, disease incidence, and mortality are among the most important parameters to monitor during a calf's pre weaning period as they reflect the overall outcome of farm management practices and husbandry. Elsohaby et al. (2019) reported that two measures of success for a calf rearing program are body weight and average daily gain.

Calf suckling is an interesting as well as extremely important area of research, because it involves such different 
aspects as behaviour, physiology and management (De passille, 2001).

This study was conducted in a commercial cattle farm using records including some factors such as season of birth, birth and weaning weights, gender of calves and dam calving number, to study the impact of different management systems on a growing calf.

\section{MATERIAL AND METHODS}

Records of 3691 growing Holstein Friesian calves raised in a commercial farm named El-Baiomy dairy farm located in Gamasa-Dakahlia province, Egypt were used in the present study. This farm specialized in milk production, consisted of 2000 Frisian dairy cattle and their consequent, daily milk production ranges between 30-32 ton/day of fresh milk in average.

\section{Management}

\section{Housing system}

This farm included two management systems (two stations). Dairy cows in both management systems were housed in a similar pens as loosing housing system in open half-shaded pens (Fig.1), while the calves were housed in different housing systems. In the 1stmanagement system, the calves were housed individually in special boxes for the first 21 days after birth (Fig. 2) and then they were relocated in conventional boxes (Fig. 3) on sand bedding till weaning. The boxes were placed in parallel rows in special contiguous boxes, with a floor of iron insulated with a plastic layer, under a large galvanized iron sheet with a height of 5 meters and raised from the ground $20 \mathrm{~cm}$. Boxes were installed on concrete floors with tendencies to facilitate the drainage of feces and urine away from the calves. The dimension of these boxes were $110 \times 70 \times 100 \mathrm{~cm}$ for long, wide and height respectively. Scalded metal barrier was provided between each animal to prevent calves licking behavior. After the first period of calving (starting from 22 day up to weaning) the calves were relocated on sand bedding in iron conventional boxes (Fig. 3). These boxes measured $200 \times 100 \times 115 \mathrm{~cm}$ for long, wide and height, respectively and were sheeted entirely and individually by galvanized iron. The starter vessels were available allover 24 hours. On the other hand, calves in 2ndstation were housed directly after birth in the conventional calf's boxes, as illustrated previously, till weaning (Fig.3).

\section{Suckling and feeding systems}

The same suckling and feeding systems were applied in both stations, they differ only according to year strategies (Table 1).

\section{Statistical analysis}

The effect of management related factors on calves' performance were statistically declared using the general linear model of IBM SPSS (statistical package) according to the following model:

$Y_{i j k l m}=\mu+H_{i}+G_{j}+S_{k}+K_{1}+H_{G S K} K_{i j k l m}+$ $\mathbf{e}_{\mathrm{ijk} k \mathrm{~m}}$

Where:

$\mathrm{Y}_{\mathrm{ijklm}} \quad$ Criteria studied for animals in the ijkl subclass;

$\mu \quad$ Overall mean;

$H_{i} \quad$ The fixed effect due to the $i_{\text {th }}$ calves housing system, $i=1,2$; where: $1=$ semi indoor system in $1^{\text {st }}$ station, $2=$ outdoor system in $2^{\text {nd }}$ station;

$G_{j}$ The effect due to the $j_{t h}$ calf gender, $\mathrm{j}=1$, 2; where:

$1=$ female,

$2=$ male;

$S_{k} \quad$ The effect due to the $k_{t h}$ season, $k=1,2,3,4$; where:

1=winter,(December-JanuaryFebruary)

2= spring, (March-April-May)

$3=$ summer, (June-July- August)

4=autumn; (September -OctoberNovember)

$K_{\mathrm{I}} \quad$ The effect due to the $I_{\text {th }}$ suckling systems, I = 1, 2, 3,4; where: 


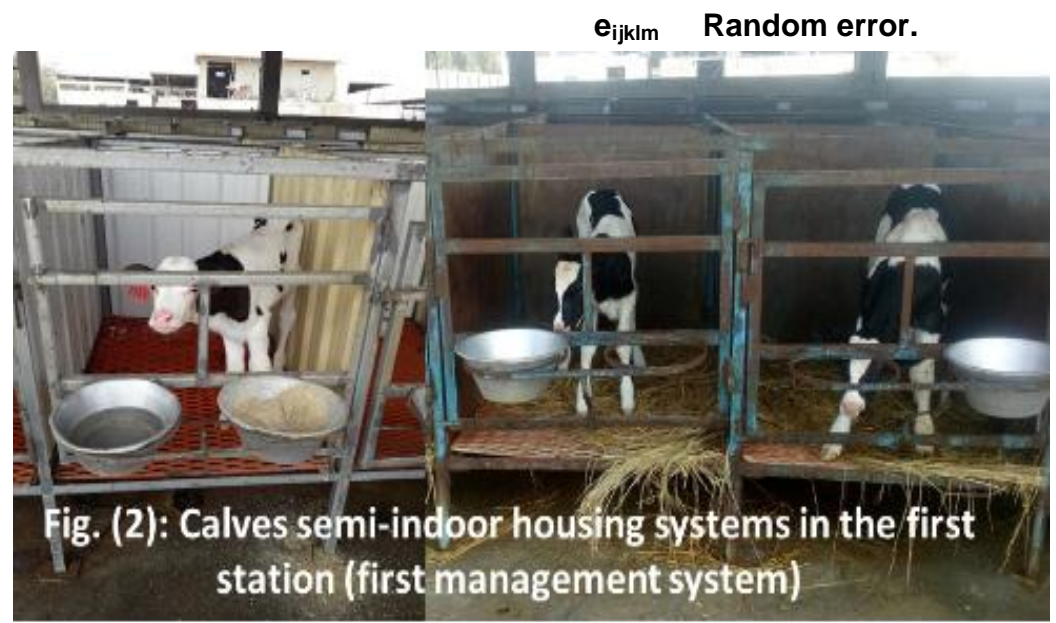

$1=1^{\text {st }}$ suckling system, $\left(1^{\text {st }}\right.$ SS at 2013),

$2=2^{\text {nd }}$ suckling system $\left(2^{\text {nd }}\right.$ SS at 2014),

$3=3^{\text {rd }}$ suckling system $\left(3^{\text {rd }}\right.$ SS at 2015 and 2016,

$4=4^{\text {th }}$ suckling system $\left(4^{\text {th }}\right.$ SS at 2017 - 2019)
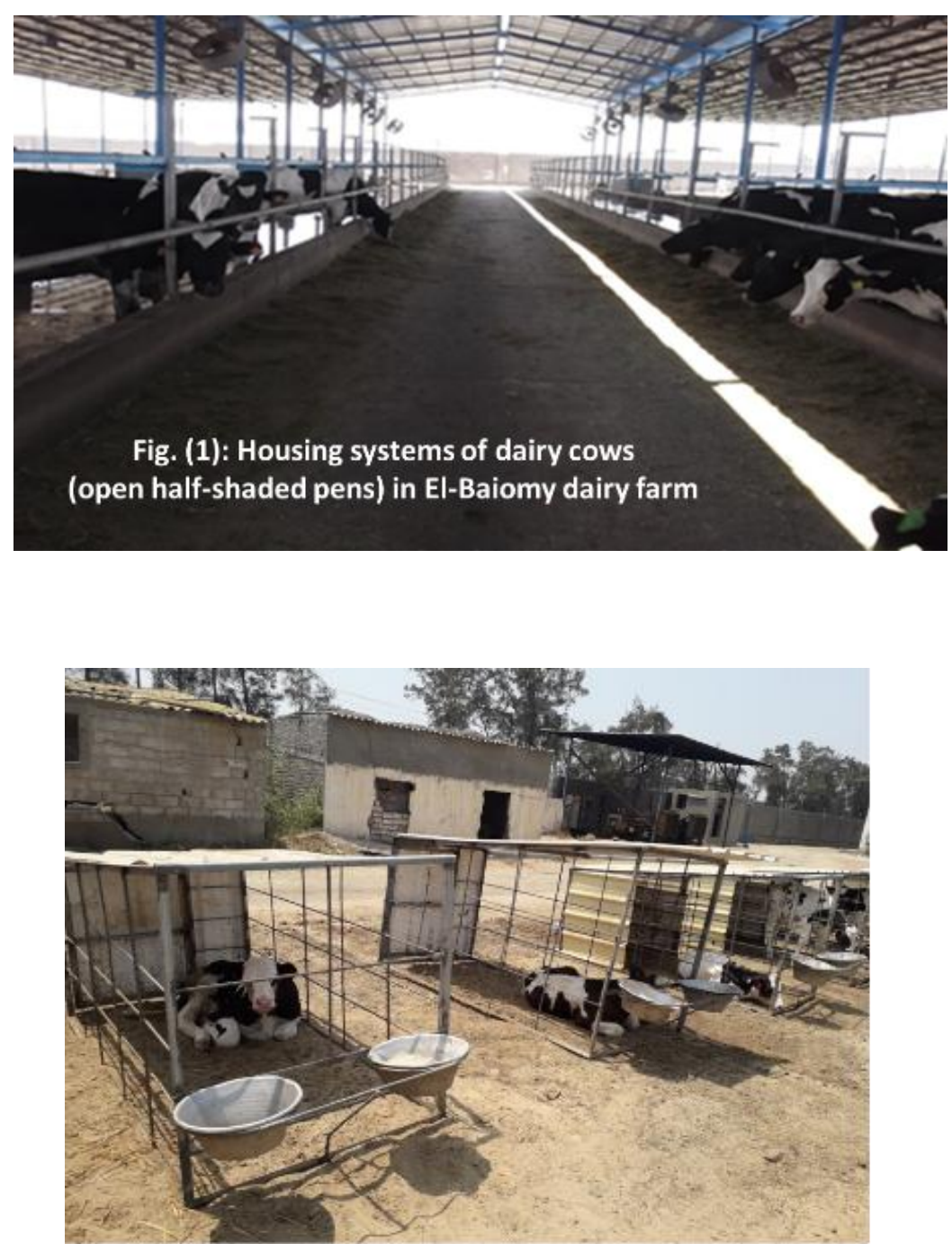

Fig. (3): Calves outdoor housing systems in the second station (second management system) 
S. Elkaschab, et al.,

Table 1: Suckling and feeding systems applied during the study (2013-2019).

\begin{tabular}{|c|c|c|}
\hline $\begin{array}{c}\text { Time from } \\
\text { parturition (00) }\end{array}$ & Year & Calves suckling and feeding systems \\
\hline 00:00 -00:30 & \multirow{7}{*}{ 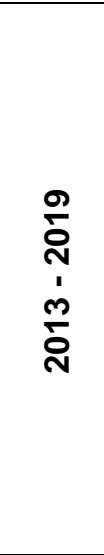 } & 2-3 kg colostrum \\
\hline 00:30 -03:00 & & 2 kg colostrum \\
\hline 03:00 -06:00 & & $2 \mathrm{~kg}$ colostrum \\
\hline $\begin{array}{l}\text { 06:00 }-72: 00 \\
\text { (for } 3 \text { days) }\end{array}$ & & $\begin{array}{c}7.5 \mathrm{~kg} \text { colostrum per day on } 3 \text { times with an } \\
\text { average } 2.5 \mathrm{~kg} / \mathrm{times}\end{array}$ \\
\hline $\begin{array}{l}\text { 72:00 -96:00 } \\
\text { (day 4) }\end{array}$ & & $\begin{array}{l}4 \mathrm{~kg} \text { mixture of whole milk and colostrum (1:1 } \\
\text { resp.) on } 2 \text { times with an average } 2 \mathrm{~kg} / \mathrm{times}\end{array}$ \\
\hline $\begin{array}{l}\text { 96:00 -120:00 } \\
\text { (day 5) }\end{array}$ & & $\begin{array}{l}4 \mathrm{~kg} \text { mixture of whole milk and colostrum ( } 3: 1 \\
\text { resp.) on } 2 \text { times with an average } 2 \mathrm{~kg} / \mathrm{times}\end{array}$ \\
\hline $\begin{array}{l}\text { 120:00 -144:00 } \\
\text { (day 6) }\end{array}$ & & $\begin{array}{c}4 \mathrm{~kg} \text { of whole milk on } 2 \text { times with an average } 2 \\
\mathrm{~kg} / \text { times \& starter }\end{array}$ \\
\hline Day 7 - day 21 & 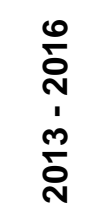 & $\begin{array}{c}5 \mathrm{~kg} \text { of whole milk/day offered on twice } \& \text { ad-lib } \\
\text { starter }\end{array}$ \\
\hline Day 21 - day 50 & \multirow{2}{*}{$\stackrel{m}{N}^{m}$} & $\begin{array}{c}6 \mathrm{~kg} \text { of whole milk/day offered on twice } \& \text { ad-lib } \\
\text { starter }\end{array}$ \\
\hline day 50 - weaning & & $\begin{array}{c}7 \mathrm{~kg} \text { of whole milk/day offered on twice \& ad-lib } \\
\text { starter }\end{array}$ \\
\hline Day 21 - weaning & 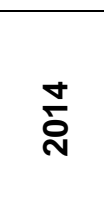 & $\begin{array}{c}\text { Male: } 6 \mathrm{~kg} \text { of replaced milk ( } 1 \mathrm{~kg} \text { of powder solve } \\
\text { in } 6 \mathrm{~kg} \text { of water)/day offered on twice \& ad-lib } \\
\text { starter } \\
\text { female: } 6 \mathrm{~kg} \text { of whole milk/day offered on twice } \\
\& \text { ad-lib starter }\end{array}$ \\
\hline Day 21 - weaning & 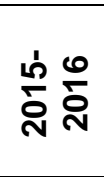 & $\begin{array}{c}\text { Male: } 6 \mathrm{~kg} \text { of antibiotic milk (waste milk)/day } \\
\text { offered on twice } \& \text { ad-lib starter } \\
\text { female: } 6 \mathrm{~kg} \text { of replaced milk /day offered on } \\
\text { twice \& ad-lib starter }\end{array}$ \\
\hline Day 7 - day 14 & \multirow{2}{*}{$\frac{\substack{\text { N } \\
\text { N }}}{\text { م }}$} & $\begin{array}{c}5 \mathrm{~kg} \text { of whole milk/day offered on twice \& ad-lib } \\
\text { starter. }\end{array}$ \\
\hline Day 14 - weaning & & $\begin{array}{c}\text { the amount of milk that offered to calves were } \\
\text { elevated } 1 \mathrm{~kg} \text { every } 7 \text { days up to day } 56 \text { the } \\
\text { amount was decreased } 1 \mathrm{~kg} \text { weekly up to } \\
\text { weaning }\end{array}$ \\
\hline
\end{tabular}

\section{RESULTS AND DISCUSSION}

\section{Managing housing systems}

There was a significant effect $(P<0.05)$ of housing systems on weaning weight, weaning age and daily gain (Table 2). It could be seen that the greatest weaning weight was been $94.59 \pm 4.99 \mathrm{~kg}$ in outdoor system, while it was $90.40 \pm 8.35$ $\mathrm{kg}$ in semi indoor system. Accordingly, the highest weaning age was $84.51 \pm 8.79$ days in outdoor system and $76.46 \pm 10.64$ days in semi indoor system. Furthermore, it is clearly appearing that daily gain was $0.77 \pm 0.11 \mathrm{~kg} / \mathrm{day}$ and $0.79 \pm 0.07 \mathrm{~kg} / \mathrm{day}$ in semi-indoor and outdoor systems, respectively. 
Table (2): Means \pm standard deviation ( $\bar{X} \pm S D$ ) for calves' performance in different housing systems

\begin{tabular}{|c|c|c|c|c|c|}
\hline \multirow{2}{*}{$\begin{array}{c}\text { Housing } \\
\text { systems }\end{array}$} & \multirow{2}{*}{ № } & $\begin{array}{c}\text { Birth weight } \\
\text { (kg) }\end{array}$ & $\begin{array}{c}\text { Weaning } \\
\text { weight (kg) }\end{array}$ & $\begin{array}{c}\text { Weaning } \\
\text { age (day) }\end{array}$ & $\begin{array}{c}\text { Daily gain } \\
\text { (kg/day) }\end{array}$ \\
\cline { 3 - 6 } & & $\bar{X} \pm$ SD & $\bar{X} \pm$ SD & $\bar{X} \pm$ SD & $\bar{X} \pm$ SD \\
\cline { 3 - 6 } & & 32.32 & $90.40^{\mathrm{b}}$ & $76.46^{\mathrm{b}}$ & $0.77^{\mathrm{b}}$ \\
\hline Semi-indoor & \multirow{2}{*}{ system } & \pm 64.20 & \pm 8.35 & \pm 10.64 & \pm 0.11 \\
\hline Outdoor system & \multirow{2}{*}{1727} & 32.24 & $94.59^{\mathrm{a}}$ & $84.51^{\mathrm{a}}$ & $0.79^{\mathrm{a}}$ \\
& & \pm 3.71 & \pm 4.99 & \pm 8.79 & \pm 0.07 \\
\hline Overall Means & 3691 & 32.28 & 92.49 & 80.22 & 0.78 \\
& & \pm 3.98 & \pm 7.29 & \pm 10.61 & \pm 0.09 \\
\hline
\end{tabular}

a,b within each column means differ significant $(P<0.05)$.

These results are in agreement with that observed by (Razzaque et al., 2009) who found, the average daily live weight gain was significantly $(P<0.05)$ higher in calves housed in hutches than conventional housing system (closed houses) (413 vs. $113 \mathrm{~g} / \mathrm{h} / \mathrm{d}$; P $\leq 0.0001)$. Stull and Reynolds (2008) revealed that housing calves individually has been recognized as a housing practice that optimizes care for young calves by maximizing the ability of farm workers to identify sick calves quickly, reduce the spread of pathogens in the calf herd by minimizing physical contact between calves. On the other hand, calves housed in pairs tended to have greater average daily gain compared with calves housed individually $(0.63$ vs. $0.59 \pm 0.02 \mathrm{~kg} / \mathrm{d}$, respectively) by Pempek et al. (2016).

Chua et al. (2002) said that there were no differences between groups or individual housing in the amounts of milk, starter, or hay consumed, or in the incidence of scouring.

\section{Managing suckling systems}

There was significant effect $(P<0.05)$ of suckling systems on weaning weight, weaning age and daily gain (Table 3 ). The highest weaning weight was94.47 \pm 5.64 $\mathrm{kg}$ in $4^{\text {th }} \mathrm{SS}$ followed by $88.43 \pm 7.95 \mathrm{~kg}$ in $3^{\text {rd }} \mathrm{SS}$, then $86.81 \pm 9.63 \mathrm{~kg}$ in $1^{\text {st }} \mathrm{SS}$ and finally $85.34 \pm 8.57 \quad \mathrm{~kg}$ in $2^{\text {nd }}$ SS. Dramatically, the average daily gain accounting $\quad 0.80 \pm 0.10 \mathrm{~kg} / \mathrm{day}$ and $0.78 \pm 0.08 \mathrm{~kg} / \mathrm{day}$ in $3^{\text {rd }}$ SS and $4^{\text {th }}$ SS respectively, followed by $0.74 \pm 0.12$ $\mathrm{kg} /$ day in $1^{\text {st }} \mathrm{SS}$ and finally $0.66 \pm 0.12$ $\mathrm{kg} /$ day in $2^{\text {nd }} \mathrm{SS}$.

These results were in agreement with that observed by Yavuz et al. (2015) who reported that, high level of milk feeding enhanced live weight and body frame size, growth rate of calves and improved feed efficiency, but evidently $8 \mathrm{~L}$ milk per calf per day increased stress of transition from liquid to dry feed at weaning. It seems that increasing the transition period to dry feed to two weeks will avoid any slump in growth. Level of milk feeding did not affect health status of calves pre- and post-weaning. Yavuz et al. (2015) added that the growth and development of calves after weaning did 
S. Elkaschab, et al.,

not depend on the level of milk feeding

before weaning.

Table (3): Means \pm standard deviation ( $\bar{X} \pm S D$ ) for calves' performance in different suckling systems (SS)

\begin{tabular}{|c|c|c|c|c|}
\hline \multirow{3}{*}{$\begin{array}{c}\text { Suckling } \\
\text { systems (SS) }\end{array}$} & \multirow{3}{*}{ № } & \multicolumn{3}{|c|}{ Calves' performance } \\
\hline & & $\begin{array}{l}\text { Weaning } \\
\text { weight }(\mathrm{kg})\end{array}$ & $\begin{array}{l}\text { Weaning age } \\
\text { (day) }\end{array}$ & $\begin{array}{c}\text { Daily gain } \\
\text { (kg/day) }\end{array}$ \\
\hline & & $\bar{X} \pm \mathrm{SD}$ & $\bar{X} \pm \mathrm{SD}$ & $\bar{X} \pm \mathrm{SD}$ \\
\hline $1^{\text {st }} \mathrm{SS}$ & 58 & $\begin{array}{r}86.81^{g} \\
\pm 9.63\end{array}$ & $\begin{array}{l}73.34^{\mathrm{fg}} \\
\pm 12.87\end{array}$ & $\begin{array}{l}0.74^{g} \\
\pm 0.12\end{array}$ \\
\hline $2^{\text {nd }} S S$ & 254 & $\begin{array}{l}85.34^{f} \\
\pm 8.57\end{array}$ & $\begin{array}{r}74.99^{g} \\
\pm 12.17\end{array}$ & $\begin{array}{c}0.66^{f} \\
\pm 0.12\end{array}$ \\
\hline $3^{\text {rd }} S S$ & 832 & $\begin{array}{c}88.43^{h} \\
\pm 7.95\end{array}$ & $\begin{array}{l}72.11^{f} \\
\pm 8.27\end{array}$ & $\begin{array}{l}0.80^{h} \\
\pm 0.10\end{array}$ \\
\hline $4^{\text {th }} \mathrm{SS}$ & 2547 & $\begin{array}{l}94.47^{i} \\
\pm 5.64\end{array}$ & $\begin{array}{c}83.55^{\mathrm{h}} \\
\pm 9.27\end{array}$ & $\begin{array}{l}0.78^{h} \\
\pm 0.08\end{array}$ \\
\hline Overall means & 3691 & $\begin{array}{l}88.76 \\
\pm 7.28\end{array}$ & $\begin{array}{c}76.00 \\
\pm 10.61\end{array}$ & $\begin{array}{c}0.75 \\
\pm 0.09\end{array}$ \\
\hline
\end{tabular}

i, $\mathrm{g}, \mathrm{h}, \mathrm{i}$, within each column means differ highly significant $(\mathrm{P}<0.01)$.

The best suckling system was found for calves weighing $\leq 30 \mathrm{~kg}$ at birth was the $1^{\text {st }}$ suckling system who showed the highest daily gain $0.85 \pm 0.19 \mathrm{~kg} / \mathrm{day}$. However, calves reared under the $4^{\text {th }}$ suckling system with higher birth weight ( $\geq 35 \mathrm{~kg}$ ), represents the highest daily gain $(0.75 \pm 0.09 \mathrm{~kg} /$ day $)$. These results shown in Table 4.

A high daily gain obtained through a high milk intake is not necessarily beneficial, because it results in a decreased intake of roughage, and hence delayed rumen development, and increases the difficulties associated with weaning-separation (Jonasen and Krohn, 1991). As maintained earlier, the daily gain of suckling calves will depend on the amount of milk available per calf (Krohn, 2001).

\section{Managing calving seasons}

There was significant effect $(P<0.05)$ of seasons of calving on weaning weight, weaning age but only significant effect $(P$ $<0.05$ ) on daily gain, while it didn't have any significant effect $(P>0.05)$ on birth weight. Fig. 4 and 5 showed that the lowest birth weight of calves found in winter $(31.34 \pm 3.86 \mathrm{~kg})$, while it was almost equal in the other seasons, spring, summer and autumn $(32.67 \pm 4.03$ $\mathrm{kg}, 32.73 \pm 3.99 \mathrm{~kg}$ and $32.70 \pm 3.92 \mathrm{~kg}$, respectively). Calves weaning weight reach the highest value with $93.88 \pm 6.53$ $\mathrm{kg}$ in winter followed by $92.54 \pm 6.47 \mathrm{~kg}$, $91.78 \pm 8.36 \mathrm{~kg}$ and $90.47 \pm 8.21 \mathrm{~kg}$ in autumn, spring and summer respectively. The lowest daily gain was found in spring $(0.74 \pm 0.11 \mathrm{~kg} /$ day) while calves born in winter, summer and autumn had the same trend $(0.78 \pm 0.09 \mathrm{~kg} / \mathrm{day})$. 
Table (4): Means \pm standard deviation ( $\overline{\mathrm{X}} \pm \mathrm{SD}$ ) for calves' performance with different birth weight and different suckling systems

\begin{tabular}{|c|c|c|c|c|c|c|}
\hline & \multirow{2}{*}{$\begin{array}{c}\text { Calves } \\
\text { performance }\end{array}$} & \multicolumn{3}{|c|}{ Birth weight } & \multirow{2}{*}{$\begin{array}{l}\text { Overall } \\
\text { means }\end{array}$} \\
\hline & & & $\leq 30 \mathrm{~kg}$ & $30-35 \mathrm{~kg}$ & $\geq 35 \mathrm{~kg}$ & \\
\hline \multirow{12}{*}{ 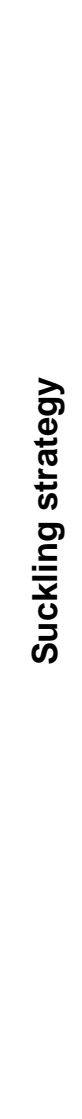 } & \multirow{3}{*}{$\begin{array}{c}\mathscr{S} \\
\stackrel{5}{\oplus}\end{array}$} & $\begin{array}{l}\text { weaning weight } \\
(\mathrm{kg})\end{array}$ & $\begin{array}{r}85.33 \\
\pm 10.59\end{array}$ & $\begin{array}{l}87.39 \\
\pm 9.43\end{array}$ & $\begin{array}{r}85.45 \\
\pm 10.56\end{array}$ & $\begin{array}{l}86.81 \\
\pm 9.62\end{array}$ \\
\hline & & $\begin{array}{c}\text { weaning age } \\
\text { (day) }\end{array}$ & \begin{tabular}{|c|}
74.16 \\
\pm 15.61 \\
\end{tabular} & $\begin{array}{c}73.44 \\
\pm 11.61 \\
\end{array}$ & \begin{tabular}{|c|}
72.54 \\
\pm 16.78 \\
\end{tabular} & $\begin{array}{l}73.34^{\mathrm{ab}} \\
\pm 12.87 \\
\end{array}$ \\
\hline & & $\begin{array}{c}\text { Daily gain } \\
\text { (kg/day) }\end{array}$ & $\begin{array}{c}0.85 \\
\pm 0.19\end{array}$ & $\begin{array}{c}0.75 \\
\pm 0.11\end{array}$ & $\begin{array}{c}0.65 \\
\pm 0.07 \\
\end{array}$ & $\begin{array}{l}0.74^{g} \\
\pm 0.12\end{array}$ \\
\hline & \multirow{3}{*}{ 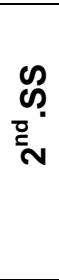 } & $\begin{array}{c}\text { weaning weight } \\
(\mathrm{kg})\end{array}$ & $\begin{array}{l}85.82 \\
\pm 7.99 \\
\end{array}$ & $\begin{array}{l}85.48 \\
\pm 8.49 \\
\end{array}$ & $\begin{array}{l}85.08 \\
\pm 8.80 \\
\end{array}$ & $\begin{array}{l}85.34 \\
\pm 8.57 \\
\end{array}$ \\
\hline & & $\begin{array}{c}\text { weaning age } \\
\text { (day) }\end{array}$ & $\begin{array}{r}80.00 \\
\pm 15.87\end{array}$ & $\begin{array}{r}75.53 \\
\pm 11.79\end{array}$ & $\begin{array}{r}73.69 \\
\pm 12.19\end{array}$ & $\begin{array}{l}74.99^{9} \\
\pm 12.17\end{array}$ \\
\hline & & $\begin{array}{c}\text { Daily gain } \\
\text { (kg/day) }\end{array}$ & $\begin{array}{c}0.77 \\
\pm 0.12 \\
\end{array}$ & $\begin{array}{c}0.69 \\
\pm 0.11 \\
\end{array}$ & $\begin{array}{c}0.62 \\
\pm 0.11 \\
\end{array}$ & $\begin{array}{c}0.66^{f} \\
\pm 0.11 \\
\end{array}$ \\
\hline & \multirow{3}{*}{$\begin{array}{l}\text { की } \\
\text { के }\end{array}$} & $\begin{array}{c}\text { weaning weight } \\
(\mathrm{kg})\end{array}$ & $\begin{array}{l}87.66 \\
\pm 7.28 \\
\end{array}$ & $\begin{array}{l}88.60 \\
\pm 7.91\end{array}$ & $\begin{array}{c}90.14 \\
\pm 10.06\end{array}$ & $\begin{array}{l}88.43^{f} \\
\pm 7.95\end{array}$ \\
\hline & & $\begin{array}{c}\text { weaning age } \\
\text { (day) }\end{array}$ & $\begin{array}{l}72.18 \\
\pm 8.05\end{array}$ & $\begin{array}{l}72.07 \\
\pm 8.27\end{array}$ & $\begin{array}{l}72.05 \\
\pm 9.08\end{array}$ & $\begin{array}{l}72.11 \\
\pm 8.27\end{array}$ \\
\hline & & $\begin{array}{c}\text { Daily gain } \\
\text { (kg/day) }\end{array}$ & $\begin{array}{c}0.84 \\
\pm 0.09 \\
\end{array}$ & $\begin{array}{c}0.78 \\
\pm 0.09 \\
\end{array}$ & $\begin{array}{r}0.69 \\
\pm 0.08 \\
\end{array}$ & $\begin{array}{l}0.80^{\mathrm{h}} \\
\pm 0.10\end{array}$ \\
\hline & \multirow{3}{*}{ 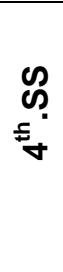 } & $\begin{array}{c}\text { weaning weight } \\
(\mathrm{kg})\end{array}$ & $\begin{array}{l}93.11 \\
\pm 5.48\end{array}$ & $\begin{array}{l}94.49 \\
\pm 5.30 \\
\end{array}$ & $\begin{array}{l}95.88 \\
\pm 7.22 \\
\end{array}$ & $\begin{array}{l}94.47^{9} \\
\pm 5.64\end{array}$ \\
\hline & & $\begin{array}{c}\text { weaning age } \\
\text { (day) }\end{array}$ & \begin{tabular}{|c|}
86.19 \\
\pm 10.15 \\
\end{tabular} & $\begin{array}{l}82.93 \\
\pm 8.58 \\
\end{array}$ & $\begin{array}{l}81.31 \\
\pm 8.74 \\
\end{array}$ & $\begin{array}{l}83.18^{h} \\
\pm 8.93\end{array}$ \\
\hline & & $\begin{array}{c}\text { Daily gain } \\
\text { (kg/day) }\end{array}$ & $\begin{array}{c}0.81 \\
\pm 0.09\end{array}$ & $\begin{array}{c}0.78 \\
\pm 0.08\end{array}$ & $\begin{array}{c}0.75 \\
\pm 0.09\end{array}$ & $\begin{array}{l}0.78^{h} \\
\pm 0.08\end{array}$ \\
\hline
\end{tabular}

$\mathrm{SS}=$ suckling systems- $a, b, c$ within each column means differ significant $(P<0.05)$.

$f, g, h, i$, within each column means differ highly significant $(P<0.01)$.

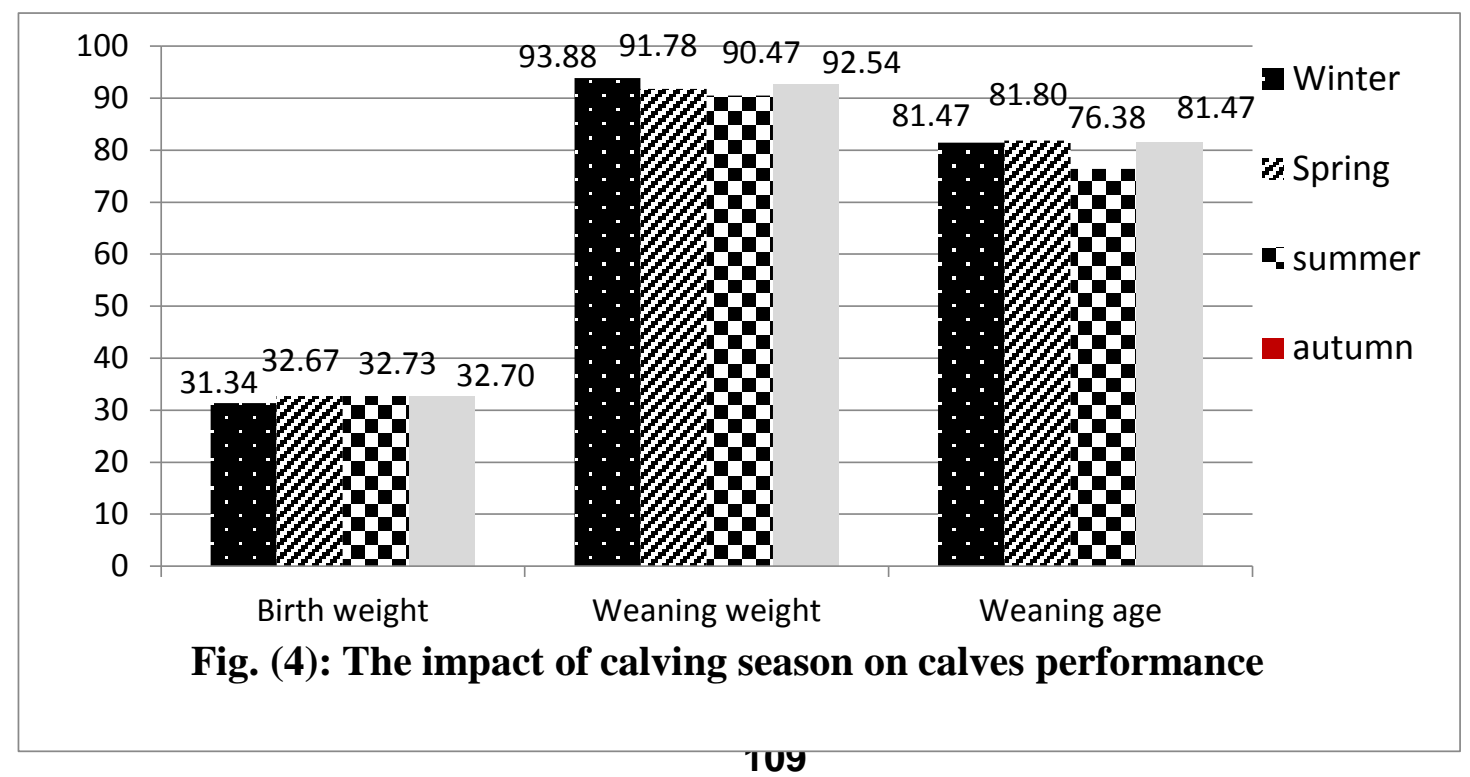




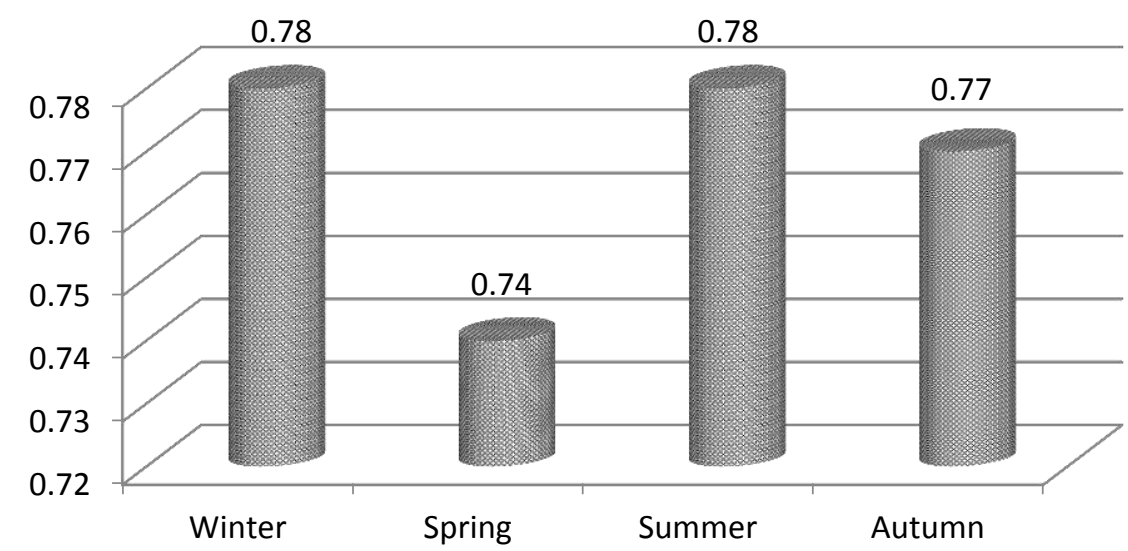

Fig. (5): The impact of calving season on calves daily gain

These results were in agreement with that observed by (Yaylak et al., 2015) who mentioned that, lower weaning weights in spring were expected because of increasing disease-causing microorganisms and disease carrying flies together with increasing temperatures. Thusly, diseases are mostly observed in spring months. Mpofu et al. (2017) and Bahashwan (2016) said that season had a significant $(P<0.05)$ effect on birth weight $(B W)$, preweaning average daily gain and weaning weight.

On the other hand, these results were in agreement with findings of Thevarnanoharan et al., (2001)who noted that birth weights of calves born during winter was the least $(29.661 \mathrm{~kg})$ while those of calves born in summer was $(30.939 \mathrm{~kg})$ followed by the birth weight of the calves born during spring.

\section{Managing calves' gender}

It was clearly appearing (Table 5) that the greatest birth weight was been $32.93 \pm 4.04 \mathrm{~kg}$ in male while the lowest one was been for female $(31.63 \pm 3.81 \mathrm{~kg})$. Furthermore, weaning age was been $81.31 \pm 10.39$ days and $79.14 \pm 10.71$ days in female and male respectively. Weaning weight and daily gain were been almost equal $(92.36 \pm 7.28 \mathrm{~kg} / \mathrm{day}$ and $0.78 \pm 0.09$ $\mathrm{kg} /$ day) in female and male respectively.

These results were in agreement with that observed by (Ugurluet al., 2016) and Abera et al. (2012) who stated that birth weight and weaning weight was significantly influenced by sex of calf $(P<0.05)$. This was attributed to the longer gestation period of male calves or higher concentration of growth hormone in male, however Bayrıl and Yilmaz (2010) was not able to identify any significant differences in weaning weights of genders.

\section{The effects of interactions among some criteria studied}

Table 6 shows the interaction among some criteria of calves performance on one hand and some management criteria on the other hand. The interaction between housing systems and calves' gender was highly significant $(P<0.01)$ on birth weight but only significant $(P<$ 0.05 ) on weaning age and daily gain and non-significant on weaning weight.

On the other hand, the interaction within management criteria and calves performance (housing $x$ season), (gender $x$ suckling) and (season $x$ suckling) were highly significant on birth weight, 
weaning weight, weaning age and daily

gain.

Table (5): Means \pm standard deviation $(\overline{\mathrm{X}} \pm S D)$ for calves' performance in different gender

\begin{tabular}{|c|c|c|c|c|c|}
\hline \multirow{3}{*}{ Gender } & \multirow{3}{*}{ № } & \multicolumn{4}{|c|}{ calves' performance } \\
\hline & & $\begin{array}{c}\text { Birth } \\
\text { weight(kg) }\end{array}$ & $\begin{array}{c}\text { Weaning } \\
\text { weight(kg) }\end{array}$ & $\begin{array}{l}\text { Weaning } \\
\text { age(day) }\end{array}$ & $\begin{array}{c}\text { Daily gain } \\
\text { (kg/day) }\end{array}$ \\
\hline & & $\bar{X} \pm \mathrm{SD}$ & $\bar{X} \pm \mathbf{S D}$ & $\bar{X} \pm \mathrm{SD}$ & $\bar{X} \pm \mathbf{S D}$ \\
\hline Female & 1845 & $\begin{array}{c}31.63^{\mathrm{g}} \\
\pm 3.81\end{array}$ & $\begin{array}{l}92.05 \\
\pm 6.83\end{array}$ & $\begin{array}{l}81.31^{9} \\
\pm 10.39\end{array}$ & $\begin{array}{r}0.78 \\
\pm 0.09\end{array}$ \\
\hline Male & 1846 & $\begin{array}{l}32.93^{f} \\
\pm 4.04\end{array}$ & $\begin{array}{l}92.67 \\
\pm 7.71\end{array}$ & $\begin{array}{l}79.14^{f} \\
\pm 10.71\end{array}$ & $\begin{array}{c}0.77 \\
\pm 0.10\end{array}$ \\
\hline $\begin{array}{l}\text { Overall } \\
\text { means }\end{array}$ & 3691 & $\begin{array}{l}32.28 \\
\pm 3.98\end{array}$ & $\begin{array}{l}92.36 \\
\pm 7.28\end{array}$ & $\begin{array}{c}80.23 \\
\pm 10.61\end{array}$ & $\begin{array}{r}0.78 \\
\pm 0.09\end{array}$ \\
\hline
\end{tabular}

i, g, within each column means differ highly significant $(P<0.01)$.

Table (6): Interaction among calves' management criteria in different calves' performance

\begin{tabular}{|c|c|c|c|c|}
\hline \multirow[b]{2}{*}{$\begin{array}{l}\text { Interactions } \\
\text { criteria }\end{array}$} & \multicolumn{4}{|c|}{ calves' performance } \\
\hline & $\begin{array}{l}\text { Birth weight } \\
(\mathrm{kg})\end{array}$ & $\begin{array}{c}\text { Weaning } \\
\text { weight }(\mathbf{k g})\end{array}$ & $\begin{array}{l}\text { Weaning } \\
\text { age(day) }\end{array}$ & $\begin{array}{c}\text { Daily gain } \\
\text { (kg/day) }\end{array}$ \\
\hline Housing x Gender & $* *$ & NS & * & * \\
\hline Housing $x$ Season & $* *$ & $* *$ & $* *$ & $* *$ \\
\hline Gender x Season & NS & $* *$ & $* *$ & NS \\
\hline Gender x Suckling & $* *$ & ** & $* *$ & $* *$ \\
\hline Season x Suckling & $* *$ & $* *$ & $* *$ & $* *$ \\
\hline
\end{tabular}

- $\quad P>0.05$ non-significant (NS), $P<0.01$ highly significant and $P<0.05$ significant.

\section{CONCLUSION}

According to the present study, determining the impact of management on calves' performance from birth to weaning is a very difficult task. There are so many different variables that can take place during the time of raising a calf. This has been achieved through various approaches and the main conclusions and implications are as follows:

- Housing calves in outdoor systems (hutches) seems to be preferable in terms of weaning weight, weaning age and daily gain.

- Managing adequate suckling practices can contribute positively to calves performance, also to control the suckled consumed quantity of milk, however it can also have negative effects.

- The lowest birth weight was found in winter, while it was almost equal in others seasons, however, the highest weaning weight was in winter.

- There was highly significant effect of gender on birth weight and weaning age. The highest birth weight was reported in male with shorter weaning age.

- The remarkable interaction between management systems and calves' performance proves the extent of the management's influence and its 
interference in the different production elements of the farm.

\section{Acknowledgement}

I'm greatly indebted to Dr. Mahmoud el Baiomy, Mr. Hussein salem and staff for his kind help to complete this research work in El-Baiomy dairy farm (Dakahlia province).

\section{REFERENCES}

Abera Habtamu, Solomon Abegaz and Yoseph Mekasha (2012). Influence of non-genetic factors on growth traits of Horro (Zebu) and their crosses with Holstein Friesian and Jersey cattle. International Journal of Livestock Production Vol. 3(7), pp. 72-77.

Bahashwan Salim (2016). Effect of some environmental factors on weaning weight of Dhofari calves. Livestock Research for Rural Development 28 (10):184-192.

Bayrıl, T. and O. Yilmaz (2010). Growth Performance and Survival Rate Traits in Holstein Calves raised in KazovaVasfiDiren Agriculture Farm. YYU Vet Fak. Derg., 21(3): 169-173.

Broucek, J., P. Kisac and M. Uhrincat (2009). Effect of hot temperatures on the hematological parameters, health and performance of calves. Int. J. Biometeorol. 53:201-208.

Chua, B., E. Coenen, J. van Delen and D.M. Weary (2002). Effects of Pair Versus Individual Housing on the Behavior and Performance of Dairy Calves. J. Dairy Sci. 85:360-364.

De passille Anna Marie (2001). Sucking motivation and related problems in calves. Applied Animal Behaviour Science 72(3):175-187

Elsohaby Ibrahim, Marguerite Cameron, Ahmed Elmoslemany, J. McClureTrenton, Greg Keefe (2019).
Effect of passive transfer of immunity on growth performance of pre weaned dairy calves. The Canadian Journal of Veterinary Research 2019;83:90-96.

Jonasen, B. and C.C. Krohn (1991). Cow \pm calf relations. IV. Behaviour, production and health in suckler calves (Danish Holstein \pm Friesian), 689. Report from The National Institute of Animal Science, Denmark, Frederiksberg, $43 \mathrm{pp}$ (in Danish with English summary and subtitles).

Kartal, T. Z. and Mete Yanar (2011). Effect of floor types on the growth performance and some behavioural traits of brown swiss calves. J. (Vet Med Zoot). T. 55 (77), ISSN 1392-2130.

Kaygısız, A., G. Bakır and I. Yılmaz (2012). Genetic parameters for direct and maternal effects and an estimation of breeding values for birth weight of Holstein Friesian calves. Bulg. J. Agric. Sci., 18: 117-124.

Krohn, C.C. (2001). Effects of different suckling systems on milk production, udder health, reproduction, calf growth and some behavioural aspects in high producing dairy cows a review. Applied Animal Behaviour Science 72 (2001) 271 280 .

Mpofu, T.J., M.M. Ginindza, N.A. Siwendu, K.A. Nephawe and B.J. Mtileni (2017). Effect of agro-ecological zone, season of birth and sex on pre-weaning performance of Nguni calves in Limpopo Province, South Africa. J. Trop Anim Health Prod 49:187-194.

NAHMS. The National Animal Health Monitoring System. (2007). Heifer calf health and management practices on U.S dairy operations, 2007. Accessed Mar. 1, $2015 . \quad$ www.aphis.usda. gov/animal_health/nahms/ dairy/ downloads/dairy07.

Pempek, J. A., M. L. Eastridge, S. S. Swartzwelder, K. M. Daniels and T. T. 
Yohe (2016). Housing system may affect behavior and growth performance of Jersey heifer calves. J. Dairy Sci. 99:569-578

Razzaque, M.A., S. Abbas, T. AL-Mutawa and M. Bedair (2009). Performance of pre-weaned female calves confined in housing and open environment hutches in kuwait. Pakistan Vet. J., 2009, 29(1): 1-4.

Stull, C. and J. Reynolds (2008). Calf welfare. Vet. Clin. North Am.: Food Anim. Pract. 24: 191-203.

Thakur Ankaj and Shailesh Kumar Gupta (2016). Effect of housing system on the behavior and performance of the dairy calves. J. Indian Farmer 3(3):197199.

Thevarnanoharan, K., W. Vandepitte, G. Mohiuddin and C. Chantalakhana (2001). Environmental factors affecting various growth traits of swam:p buffalo calves. Pak. 1. Agri. Sci. Vo/. 38: 3-4.

Ugurlu, M., I. Kaya and M. Saray (2016). Effects of some environmental factors on calf birth weight and milk yield of Anatolian Water Buffalo (Bubalus bubalis). Bulg. J. Agric. Sci., 22: 995998.

Yavuz, E., G. Ganchev, N. Todorov and K. Nedelkov (2015). The effect of feeding different milk programs on dairy calf growth, healthand development. Bulgarian Journal of Agricultural Science, 21 (No 2), 384-393.

Yaylak Erdal, Hikmet Orhan and Alim Daşkaya (2015). Some Environmental Factors Affecting Birth Weight, Weaning Weight and Daily Live Weight Gain of Holstein Calves. Turkish Journal of Agriculture - Food Science and Technology, 3(7): 617-622. 


\title{
تأثير إدارة تربية العجول على أدائها فى مزرعة تجارية للهولستين فريزيان
}

\author{
سمير الخشاب، سعيد سعيد عمر، إلهام محمد غنيم، أسماء سعد غانم
}

قسم الإنتاج الحيوانى ، كلية الزراعة، جامعة المنوفية

الملخص العربي

أجريت هذه الاراسة في مزرعة تجارية لانتاج الألبان في جمصة محافظة الدقهلية - مصر (تسمي مزرعة البيومي)

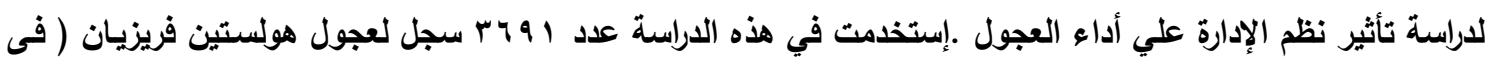

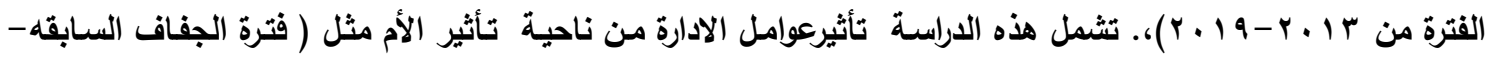

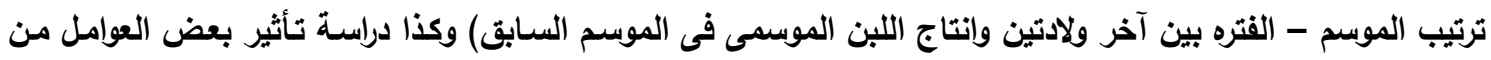

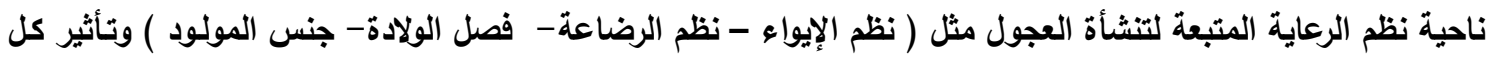

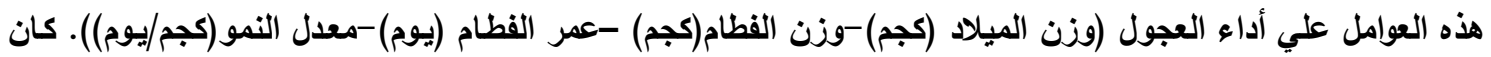

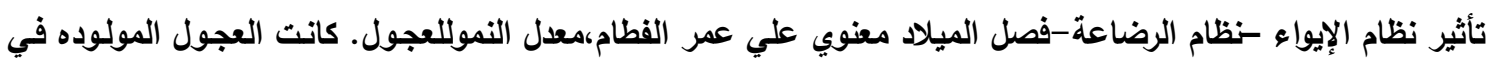

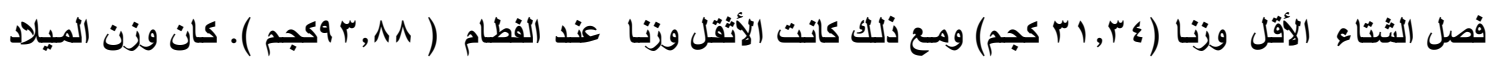

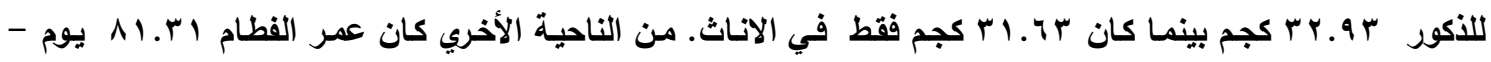

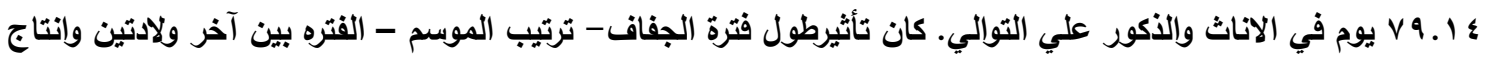

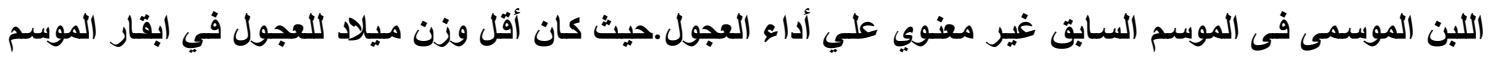

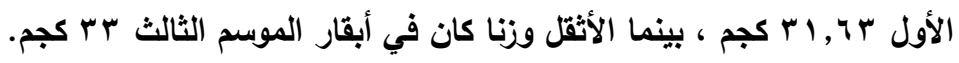


The impact of managing rearing calves on their performance in ..

$$
\begin{aligned}
& \text { أ. أد/ محمد مسعد مراد كلية الزراعة - جامعة عين شمس } \\
& \text { أ.د/ بركات محمد أحمد كلية الزراعة - جامعة المنوفية }
\end{aligned}
$$

